\title{
Pessimism Counts in Favor of Biomedical Enhancement: A Lesson from the Anti-Natalist Philosophy of P. W. Zapffe
}

\author{
Ole Martin Moen (D)
}

Received: 17 June 2020 / Accepted: 10 February 2021 / Published online: 27 March 2021

(C) The Author(s) 2021

\begin{abstract}
According to the Norwegian philosopher Peter Wessel Zapffe (1899-1990), human life is filled with so much suffering that procreation is morally impermissible. In the first part of this paper I present Zapffe's pessimism-based argument for anti-natalism, and contrast it with the arguments for anti-natalism proposed by Arthur Schopenhauer and David Benatar. In the second part I explore what Zapffe's pessimism can teach us about biomedical enhancement. I make the (perhaps surprising) case that pessimism counts in favor of pursuing biomedical enhancements. The reason is that the worse we take the baseline human condition to be, the stronger are our reasons to try to alter humanity, and the weaker are our reasons to fear technology-driven extinction. The prospect of enhancement, I further argue, gives pessimists a reason to reject antinatalism.
\end{abstract}

Keywords Anti-natalism · Existentialism · Pessimism . Suffering $\cdot$ Transhumanism $\cdot$ Welfare enhancement

O. Moen $(\bowtie)$

Faculty of Health Sciences, Oslo Metropolitan University, Box 4

St. Olavs plass, N-0130 Oslo, Norway

e-mail: olemarti@oslomet.no

\section{Introduction}

Every year, around 140 million human beings are born. ${ }^{1}$ This amounts, on average, to four births per second. Even though procreation is almost universally celebrated and encouraged, it is difficult to deny that there is an extreme moral seriousness involved in the act of bringing a new human being into existence. A child that is born might go on to live a good life, but in no case can this be guaranteed, and even the best of lives inevitably contains suffering.

Should we continue to procreate? According to antinatalism, we should not. Although anti-natalism has never been a mainstream position, it has been a persistent minority viewpoint among philosophers. Its most influential advocates are Hegesias and Sophocles in ancient Greece, Arthur Schopenhauer in the nineteenth century, and, in contemporary philosophy, David Benatar. ${ }^{2}$

In this paper I examine the anti-natalist theory of the Norwegian existentialist philosopher Peter Wessel Zapffe (1899-1990). According to Zapffe, human nature is riddled with an inherent, irresolvable conflict, the result of which is that human lives are filled with too much suffering for procreation to be morally permissible. In contrast to the God of the Old Testament, who instructs us to "be fruitful and multiply and fill the

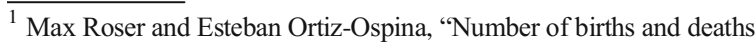
per year, World". OurWorldInData.org (University of Oxford): https://ourworldindata.org/grapher/births-and-deaths-projected-to2100 [1]

${ }^{2}$ See David Benatar, Better Never to Have Been: The Harm of Coming into Existence (Oxford: Oxford University Press, [2]).
} 
earth,"3 Zapffe instructs us, in his 1933 essay "The Last Messiah," to "be infertile and let the earth be silent after ye." 4

In Part 1 I present Zapffe's pessimismbased argument for anti-natalism, and contrast it with the arguments of Schopenhauer and Benatar. In Part 2 I use Zapffe's bleak outlook on life to explore the implications of pessimism for one of the central debates in contemporary bioethics, the debate about biomedical enhancement. I argue that pessimism counts strongly in favor of pursuing biomedical enhancements (especially welfare enhancements), and that this, in turn, gives pessimists a reason to reject anti-natalism.

\section{Part 1: Pessimism}

\section{Zapffe on the Tragedy of Human Nature}

According to Peter Wessel Zapffe, human life is inescapably very bad, the central reason for which is that there is an irresolvable conflict inherent in our nature. What does this conflict consist in? On the one hand, Zapffe explains, we humans are biological beings that, due to the evolutionary forces that have shaped us, are constantly prompted to act in ways that promote our own survival and reproduction. ${ }^{5}$ Having become the dominant species on Earth, we have, in evolutionary terms, been successful. One of the central explanations of our success, Zapffe suggests, is our advanced cognitive capacities. While cheetahs gain an evolutionary advantage by being fast and bears by being strong, we humans gain an advantage by being smart: The human intellect enables us, among other things, to make tools and traps, to cook, to plan, to communicate effectively, and to adapt quickly to changing environments.

Zapffe suggests, however, that the human intellect comes with a very significant downside: It confronts us

\footnotetext{
$\overline{3}$ Bible, 1 Gen 1:28. English Standard Version [3].

${ }^{4}$ Peter Wessel Zapffe, "The Last Messiah," translated by Gisle Tangenes, Philosophy Now, Issue 45: March/April [4]. https://philosophynow.org/issues/45/The_Last_Messiah For Zapffe's original text, written in Norwegian, see Peter Wessel Zapffe, "Den Sidste Messias" in Kulturelt nødverge, Jørge Haave (ed.) (Oslo: Pax, 1999), 51-62. With the exception of quotes from "The Last Messiah," all translations are my own. Norwegian is my native language.

${ }^{5}$ Zapffe's views on biology and psychology were heavily influenced by the German biological theorist Jakob von Uexküll. See Jakob von Uexküll, A Foray Into the Worlds of Animals and Humans: With a Theory of Meaning, translated by Joseph D. O'Neil (Minneapolis: University of Minnesota Press, [5]).
}

with our frailty, with the suffering and death that eventually awaits us, with the vastness of suffering on Earth, and with our own cosmic insignificance - and these insights, he writes, are apt to fill us with "world-angst and life-dread." While "in the beast, suffering is selfconfined, in man, it knocks holes into a fear of the world and a despair of life." One reason for fear and despair is that we humans grasp not just what is right before us; due to our "creative imagination" and "inquisitive thought," "graveyards wrung themselves before [our] gaze, the laments of sunken millennia wailed against [us] from the ghastly decaying shapes." Another reason is that, as beings with an intellectual nature, we crave justification, and thus we are uniquely confronted with, and pained by, the meaninglessness and injustice of suffering. ${ }^{7}$ This, Zapffe holds, is a secular truth behind the myth that we humans have "eaten from the Tree of Knowledge and been expelled from Paradise." 8

In order to illustrate the conflict between the biological and intellectual aspects of our nature, Zapffe tells the following parable in "The Last Messiah":

One night in long bygone times, man awoke and saw himself.

He saw that he was naked under cosmos, homeless in his own body. All things dissolved before his testing thought, wonder above wonder, horror above horror, unfolded in his mind.

Then woman too awoke and said it was time to go and slay. And he fetched his bow and arrow, a fruit of the marriage of spirit and hand, and went outside beneath the stars. But as the beasts arrived at their waterholes where he expected them of habit, he felt no more the tiger's bound in his blood, but a great psalm about the brotherhood of suffering between everything alive.

That day he did not return with prey, and when they found him by the next new moon, he was sitting dead by the waterhole. ${ }^{9}$

This man's intellect, the very capacity that enables him to hunt using bow and arrow, ends up paralyzing him by confronting him with his own brutality.

Zapffe introduces a number of metaphors to further elucidate his view. He compares the capacity to reason

\footnotetext{
${ }^{6}$ Zapffe, "The Last Messiah."

${ }^{7}$ Zapffe, Om det tragiske, 69 [6].

${ }^{8}$ Ibid.

${ }^{9}$ Zapffe, "The Last Messiah."
} 
to a sharp sword that lacks a handle. While it is a powerful weapon, whoever uses it to cut into the flesh of others inevitably also cuts into his own hand. ${ }^{10} \mathrm{He}$ further compares the human predicament to that of the Irish giant deer, which (or so the story goes) evolved cripplingly large antlers. Although the large antlers had been the Irish giant deer's distinguishing weapon in the struggle for survival, and thus the source of its greatness, the antlers became so large that they ended up causing its extinction. In a similar way, Zapffe suggests, we humans are also undermined by the very capacity that gives rise to our greatness. This makes human life tragic, since in Zapffe's view, the essence of tragedy is demise caused by greatness. This is his central claim in On the Tragic, his magnum opus, published in 1941. ${ }^{11}$

Zapffe concedes that his bleak outlook on life is likely to strike many as counterintuitive. This is so, he suggests, not because life is in fact tolerably good, but because we have developed elaborate strategies to prevent ourselves from seeing the horrors of life. He argues that such strategies, which he calls strategies of suppression, "proceed practically without interruption as long as we are awake and in action, and provide a background for social cohesion and what is popularly called a healthy and normal way of life."12

Echoing ideas from early psychoanalytic theory, Zapffe lists three central strategies of suppression: Isolation, anchoring, and distraction. Isolation is the process of isolating ourselves from unpleasant impressions by institutionalizing taboos and by ostracizing those who break them. This is most evident, he suggests, in how we protect children from the harsh realities of life: We tell them that, in the end, all will be fine and good, even though we know that, in the end, we will suffer and die, and, eventually, be forgotten. Anchoring is the process of entertaining fictions that tell us that we belong in a certain stable place, such as a family, a home, a church, a state, or a nation. "With the help of fictitious attitudes," Zapffe writes, "humans are able to behave as if the outer or inner situation were different from what honest cognition tells us."14 Finally, distraction is the process of filling our waking hours with tasks that distract us from existential dread. We keep our "attention within the critical limit by capturing it in a ceaseless bombardment of external input."15

Zapffe suggests that these mechanisms of suppression are needed to keep us from being paralyzed by fear. He maintains that one of the crucial functions of any culture is to provide effective suppression, and that many psychiatric disorders should be understood as results of a breakdown of the mechanisms of suppression. $^{16}$

In addition to isolation, anchoring, and distraction, Zapffe lists a fourth strategy: sublimation. Sublimation is the process whereby the tragedy of human life is given aesthetic value. The production and appreciation of art, Zapffe writes, is perhaps more properly called a mechanism of "transformation rather than repression."17 The reason is that while isolation, anchoring, and distraction work by trying to push suffering out of sight, sublimation confronts suffering head on and seeks to transform suffering into beauty. ${ }^{18}$

To understand how sublimation can play this role in Zapffe's worldview, it might be instructive to return to the "brotherhood of suffering" in the parable with the paralyzed hunter. When the hunter recognizes that the animal's fear and hunger is similar to his own, he includes the animal in a "brotherhood of suffering." Art provides its appreciators with the experience of being included in a brotherhood of suffering. The artist shows the art appreciators that he understands them and sees the world, at least in part, the way they see it, and thus he communicates to his fellow human beings that they are not alone.

Although art can give us consolation, however, it cannot save us from suffering, the reason for which is that the source of suffering is too deep. We suffer, Zapffe suggests, because of our very nature as humans. Insofar as we use our intellect, which, as humans, we must do in order to sustain ourselves, we are bound to suffer. Insofar as we suppress our intellectual capacities, we reject our humanity and undermine the faculty that is most crucial to our mode of survival. Humanity, therefore, is confronted with the grim fundamental alternative of having to choose either death or suffering.

\footnotetext{
$\overline{15}$ Zapffe, "The Last Messiah."

16 Ibid.

${ }^{17}$ Ibid.

18 Ibid.
}

\footnotetext{
${ }^{10}$ Ibid.

${ }^{11}$ Zapffe, Om det tragiske, 308-310.

12 Zapffe, "The Last Messiah."

13 Ibid..

${ }^{14}$ Zapffe, Om det tragiske, 69.
} 


\section{Zapffe's Theory of Value}

What ethical commitments lie behind Zapffe's negative estimation of human life? Jørgen Haave, the editor of Zapffe's collected works, suggests that Zapffe is an ethical nihilist. ${ }^{19}$ Dag O. Hessen, another Zapffe scholar, writes that Zapffe "balances at the edge of nihilism." Hessen writes that he is reluctant to call Zapffe a true nihilist, however, because Zapffe, despite having a very bleak outlook on the world, "was engaged throughout his life, on several fronts, with a clear wish to contribute": he was a rather prominent Norwegian essayist, playwright, literary theorist, mountaineer, and humorist. ${ }^{20}$ Zapffe's engagements and contributions, Hessen argues, would be paradoxical if he were a nihilist.

Was Zapffe a nihilist? This depends on how we use the term. If, by the term "nihilist," we mean someone who believes that a state of affairs in which nothing (nihil in Latin) exists would be preferable to the world as it is, Zapffe was indeed a nihilist. In the context of ethics, however, it is more common to use the term nihilism to refer to the view that nothing matters or that nothing is of any value. This, presumably, is the sense of nihilism that could make Zapffe's contributions look paradoxical, since if he believed that nothing matters, he would have believed that he could have no reason to make those contributions.

In this sense, however, Zapffe is not a nihilist; he is better described as a pessimist. While a nihilist holds that nothing matters, a pessimist holds that life is very bad. In this sense, nihilism and pessimism are not just distinct views; the views are even incompatible. The reason is that for life to be very bad, something must matter, but that is what the nihilist rejects. So while the nihilist view that nothing matters might sound bleak (since it implies that everything is in vain), nihilism is not really a bleak position, since, as Guy Kahane points out, if nihilism is true, it is not really a problem that everything is in vain. If nothing matters, it doesn't matter that nothing matters. ${ }^{21}$

If we understand Zapffe as a pessimist rather than as a nihilist, his contributions are no longer puzzling, since

\footnotetext{
${ }^{19}$ Jørgen Haave, "Innledning" in Peter Wessel Zapffe, Kulturelt nødverge: Zapffes etterlatte skrifter (Oslo: Pax forlag, [7]), 14-15.

${ }^{20}$ Dag O. Hessen, "Zapffe og den biologiske analyse" in Et liv på mange vis: En antologi om Peter Wessel Zapffe, Inga Bostad and Dag O. Hessen (red.) (Oslo: Pax forlag, [8, 9]), 88.

${ }^{21}$ Guy Kahane, "Our Cosmic Insignificance," Nous 48 (4) [10]: 745772.
}

one can have good reasons to try to make the world better even if one thinks that it is very bad. Indeed, pessimists might have even stronger reasons to contribute than optimists, insofar as it is more important to make positive contributions if the good things in this world are scarce than if they are already abundant. (Admittedly, the term "pessimist" is sometimes used to refer to someone who thinks that we are unlikely to succeed in carrying out our plans. That is not the way I use the term here.)

If Zapffe's view is that life is very bad, we might proceed to ask what is the substantive theory of value on which he bases his negative assessment of human life. What is the nature of the badness that, in his view, is made unavoidable by the conflict inherent in human nature?

One suggestion might be that, in Zapffe's view, the conflict inherent in human nature is bad in virtue of hindering our survival and reproduction. It is this conflict, after all, which explains why the hunter in Zapffe's story fails to kill the prey and thus fails to feed himself and his family. It should be evident, however, that Zapffe does not hold the view that human survival and reproduction are benign processes that, regrettably, are stifled by our conflicted nature. If that had been his view, it would be puzzling why Zapffe advocated antinatalism, since, presumably, few things can be a greater threat to human reproduction than human extinction.

An alternative suggestion could be that the conflict inherent in human nature is bad in virtue of making us aware of the brutality that characterizes the world around us. Gisle Tangenes writes that "while no living creature escapes this carnage, only humans bear the burden of awareness." 22 This explanation is more in line with Zapffe's philosophical outlook. I would like to suggest, however, that although this can be a part of the explanation, it cannot be the fundamental explanation of the badness. The reason is that for our awareness of the world's brutality and carnage to be bad, there would presumably have to be something about brutality and carnage that is bad in the first place; otherwise it would be puzzling why it would be so troublesome for us to be made aware of it.

So what is the problem with brutality and carnage? In my interpretation, the problem, in Zapffe's view, is fundamentally suffering. Although Zapffe does not

\footnotetext{
$\overline{22}$ Gisle Tangenes, "The View from Mount Zapffe," Philosophy Now, Vol. 45, [11].
} 
explicitly discuss value theory in his works, his appeals to suffering are abundant. The world is terrible, he explains, because of the "suffering of billions of people," and we find consolation in a "brotherhood of suffering." 23 In one of his later writings, Zapffe goes as far as to defend his position by appeal to "hedonic welfare." ${ }^{24}$ My claim is not that Zapffe endorsed the hedonistic position that suffering is the only thing that is bad in itself. Although Zapffe might have perhaps have held this view, he might also have held that there are other things, besides suffering, that are also bad in themselves (such as meaninglessness), or he might have remained agnostic on this issue. Irrespective of his theoretical commitments regarding intrinsic goodness and badness, however, it seems that his argument for pessimism is very straightforward: It consists of an empirical premise, that life is filled with suffering, and an evaluative premise, that suffering is bad.

How, then, does Zapffe get from this argument for pessimism to the conclusion that procreation is immoral? One premise on the path to this further conclusion is that life is not just filled with suffering, but is filled with so much suffering, and with so little happiness, that human lives tend not to be worth living. Another premise is that nothing short of extinction can bring human suffering to an end. To appreciate why he holds this premise, notice that in Zapffe's philosophy, there is no hope that social reform can solve the problem of suffering. Although social reform might perhaps alleviate some of the suffering, he takes the core problem to lie, not in the way in which society is organized, but in human nature. The problem, we might say, lies not in the rules of the game but in the internal nature of the game pieces, and therefore, we cannot expect to be able to solve the problem by changing the rules of the game. The third and last premise, which is implicitly assumed rather than explicitly stated by Zapffe, is that it is immoral to create lives that one cannot reasonably expect to be worth living. If we accept all three of these premises, we have reached the anti-natalist conclusion that it is immoral to procreate.

\footnotetext{
${ }^{23}$ Zapffe, "Den Sidste Messias," 44.

${ }^{24}$ Peter Wessel Zapffe and Herman Tønnessen, Jeg velger sannheten (Oslo: Universitetsforlaget, [12]), 17.
}

Zapffe vs. Schopenhauer vs. Benatar

How does Zapffe's argument for anti-natalism compare with the arguments of other anti-natalist philosophers? In some respects, his arguments resemble (and were indeed inspired by ${ }^{25}$ ) the arguments of Arthur Schopenhauer, who also held that "life is filled with suffering" and that, for this reason, we should cease to procreate. $^{26}$ According to Schopenhauer:

If children were brought into the world by an act of pure reason alone, would the human race continue to exist? Would not a man rather have so much sympathy with the coming generation as to spare it the burden of existence, or at any rate not take it upon himself to impose that burden upon it in cold blood? ${ }^{27}$

In what ways do their views differ? One difference is that while Schopenhauer held that a human "is generally capable of much greater sorrows than is the animal," he also held that a human can experience "greater joy in satisfied and happy emotions" than an animalis capable of experiencing. ${ }^{28}$ There is no mention, in Zapffe's works, of such an upside for humans. Another difference is that Zapffe and Schopenhauer appear to have different views on the nature of suffering. In Schopenhauer's view, we suffer because we strive to satisfy our desires. This striving, he argued, leaves us either in a state of dissatisfaction (insofar as we do not get what we strive for), or alternatively with boredom and the formation of new desires (insofar as we get it). ${ }^{29}$ For Schopenhauer, therefore, the fundamental problem does not lie in the very nature of certain qualities of experiences, but in our response to certain qualities of our experiences. So in Schopenhauer philosophy there is a glimmer of hope in that suffering will end if we reach a state in which we no longer strive but, instead, related to the world ascetically, in dispassionate contemplation (Schopenhauer was influenced by Indian philosophy, particularly Buddhism and Jainism). ${ }^{30}$ Zapffe

\footnotetext{
$\overline{25}$ Zapffe, Om det tragiske, 571.

${ }^{26}$ Arthur Schopenhauer, The World as Will and Representation, Vol. 1, translated by E. F. J. Payne (New York: Dover Publications, [13]), $\S 56$.

${ }^{27}$ Arthur Schopenhauer, Parerga and Paralipomena, Vol. 1, translated by E. F. J. Payne (Oxford: Oxford University Press [14]), 291-3.

${ }^{28}$ Schopenhauer, The World as Will and Representation, Vol. 2, §22.

${ }^{29}$ Schopenhauer, The World as Will and Representation, Vol. 1, §65.

${ }^{30}$ Ibid, $\S \S 48-49$.
} 
does not appear to believe in the elimination of striving as a way out of suffering. One explanation might be that Zapffe thinks striving is unavoidable. Another explanation might be that he locates badness, not in the way in which we respond to our experiences, but in the intrinsic quality of certain experiences. In that case we could, in theory, stop all striving, yet continue to suffer.

How does Zapffe's argument for anti-natalism compare to that of David Benatar? Like Zapffe, Benatar holds a pessimistic view of human life, according to which "people's lives are much worse than they think and ... all lives contain a great deal of bad." ${ }^{, 31}$ A crucial difference, however, is that Benatar's argument for antinatalism does not really depend on pessimism, but instead, on what he calls the asymmetry thesis.

In Benatar's view, persons benefit from being happy. Nevertheless, he argues, we cannot justify the creation of a new person by appeal to the happiness that they will come to experience if they are brought into existence. Benatar suggests that even though we do something morally good if we make an existing life happy (or if we make a life that will exist anyway happy), we do something that is at best morally neutral if we bring a new life that is happy into existence. In the former case, we fulfill a need; in the latter case, we both create and fulfill a need.

Benatar proceeds by arguing that if we fail to create a happy life, there is no one who is deprived of that happiness: "[a]lthough the good things in one's life make it go better than it otherwise would have gone, one could not have been deprived by their absence if one had not existed. Those who never exist cannot be deprived. ${ }^{32}$ So while Benatar suggests that it is morally neutral to create a happy life, he suggests that it is morally good to avert the creation of a life that would not be worth living for that person.

Here, then, is the crux: If happiness in a prospective life cannot justify its creation, but suffering in a prospective life can justify averting its creation, then as long as a prospective life is likely to contain at least some suffering we are not justified in creating it. On Benatar's view, if we could be certain that a prospective life would not contain any suffering, it would presumably be permissible to create it, but no matter how much happiness it contained, we would still not have any positive

\footnotetext{
$\overline{31}$ Benatar, Better Never to Have Been, 61.

32 Ibid.
}

reasons to create it - or at least, no positive reasons grounded in the interests of that prospective person.

Both Zapffe's and Benatar's arguments for antinatalism are based on the badness of suffering. Benatar's argument, however, does not depend on any particular empirical premise regarding the prevalence of suffering in life; instead, Benatar bases his anti-natalist conclusion on the asymmetry thesis, according to which we should weigh happiness and suffering differently in decisions about prospective lives than in decisions about existing lives. Zapffe's argument is not based on the asymmetry thesis, but on an empirical premise about the pervasiveness of suffering in human lives (i.e. pessimism). If we employ Erik Magnusson's recently proposed terms, Zapffe's argument is a "quality of life argument" for anti-natalism. ${ }^{33}$

\section{Part 2: Biomedical Enhancement}

\section{The Problem of Biomedical Enhancement}

Having considered Zapffe's pessimism-based argument for anti-natalism, let us now turn to the debate about biomedical enhancement. While these two issues might, at first glance, seem unrelated, I think there are underappreciated connections between pessimism and biomedical enhancement, and that Zapffe's ideas can help bring these to the foreground.

What is biomedical enhancement? In Alberto Giubilini and Sagar Sanyal's definition, biomedical enhancement, in the context of humans, "is the use of biotechnologies for the sake of improving human dispositions, capacities, and well-being in cases where the aim is not to treat a pathology." 34 The point is that whereas most medical interventions aim at treating or averting pathologies (such as a broken bone, cancer, or depression), the distinguishing feature of enhancements is that instead of being aimed at lifting sick individuals back up to the baseline level of functioning, they are aimed at lifting individuals up above the baseline and thus, over time, to lift the very baseline. Typical

\footnotetext{
${ }^{33}$ Erik Magnusson. "How to reject Benatar's asymmetry argument," Bioethics 33 [15]: 674-683.

${ }^{34}$ Alberto Giubilini and Sagar Sanyal, "Challenging Human Enhancement," in The Ethics of Human Enhancement: Understanding the Debate, Steve Clarke, Julian Savulescu, Tony Coady, Alberto Giubilini, and Sagar Sanyal (eds.) (Oxford: Oxford University Press, [16]): $1-24$.
} 
examples of interventions that would qualify as attempts at enhancement are attempts to use biomedical technologies to improve cognitive abilities, to increase life spans (e.g. by slowing down, stopping, or perhaps reversing ageing), and to elevate happiness above the levels that are required to qualify as healthy. In recent years, much controversy has been centered on so-called "moral enhancement," which is the prospective use of biomedical technologies to promote moral behavior (for example, by enhancing compassion, love, and kindness, and reducing propensities towards violence and aggression. $^{35}$

Should we pursue biomedical enhancements? While there is, of course, a range of positions and arguments that have been advanced, let me sketch what I take to be the basic argumentative landscape. Proponents of enhancement typically defend the idea by pointing to the significant increases in lifespans and welfare that could be brought about by the development and application of enhancement technologies, and that it should not be controversial that increases in lifespans and welfare are goods that we have reason to pursue. ${ }^{36}$ The most radical defenders of enhancement, transhumanists, argue that we should enhance a wide range of capacities, and that we should do so to such an extent that we transcend human nature and become a posthuman species. ${ }^{37} \mathrm{At}$ the opposite side of the debate, bioconservatives argue that we should not medicalize healthy states, that the pursuit of enhancement is a wrongful pursuit of perfection, and that by engaging in attempts at such pursuits, we could, in the worst case, run the risk of bringing about our own extinction. ${ }^{38}$

The way I construe the debate about biomedical enhancement, it is a normative debate, and not (or at least not primarily) an empirical debate about what technologies are available or will become available. Rather than being a debate about forecasting, it is a debate about what would be good and thus what we have reason to strive for if it becomes attainable. When

\footnotetext{
35 Thomas Douglas, "Moral enhancement," Journal of Applied Philosophy 25(3) [17]: 228-245.

${ }^{36}$ Allen E. Buchanan, Beyond Humanity? The Ethics of Biomedical Enhancement (New York: Oxford University Press, [18]).

${ }^{37}$ Nick Bostrom, "In Defense of Posthuman Dignity," Bioethics 19 (3) [19], 201-214.

${ }^{38}$ Leon R. Kass, "Ageless Bodies, Happy Souls: Biotechnology and the Pursuit of Perfection," The New Atlantis, 1 [20]: 9-28; Michael Sandel, The Case against Perfection (Cambridge, Mass.: Harvard University Press, [21]).
}

the debate is construed this way, notice that it is possible to oppose enhancement even if one thinks that enhancement technologies will become technically feasible, and likewise, it is also possible to endorse enhancement even if one thinks that, most likely, such technological advancements will never be achieved (admittedly, if one thinks that they are impossible to achieve, one's pro enhancement view would be a utopian vision without practical implications). While empirical and normative views are not always clearly distinguished in the debate about biomedical enhancement, this is a relatively mundane distinction in other debates. Take the debate about free immigration: It is clearly possible to oppose free immigration even if one thinks that it free immigration were achievable, and it is possible to defend free immigration even if one thinks that it is highly unlikely that it will ever be achieved.

What Should a Zapffian Think about Enhancement?

How should we think about the development and application of biomedical enhancement technologies if we approach the issue from a Zapffian perspective?

Let us start by considering Zapffe's own views on biotechnological progress. To my knowledge, Zapffe considers future advancements in biotechnology only on two occasions in his writings. In a dialogue with philosopher Herman Tønnessen, published in I Choose Truth, Tønnessen brings up the issue of life-extension technologies. ${ }^{39}$ Zapffe is dismissive, suggests that technology is a mechanism of distraction, that technological leisure and entertainment will always be unsatisfactory, and that technological progress has sharply diminishing marginal utility. ${ }^{40} \mathrm{He}$ provides an example involving two farmers: "The small farmer who expands his field from two to four acres, has the same experiential joy as the farmer who expands from two hundred to four hundred acres - yes, maybe bigger." ${ }^{\text {41 }}$ Although Zapffe concedes that technology can help satisfy our biological needs, such as our needs for food and shelter, he suggests this to be an impressive feat, since our biological needs are relatively easily met. Beyond food and shelter,

\footnotetext{
${ }^{39}$ Peter Wessel Zapffe and Herman Tønnessen, Jeg velger sannheten. (Oslo: Universitetsforlaget, [12]).

${ }^{40}$ Peter Wessel Zapffe," Opplevelsestilbud og opplevelsesbehov" in Peter Wessel Zapffe, Kulturelt nødverge: Zapffes etterlatte skrifter (Oslo: Pax forlag, [22]), 54.

41 Ibid.
} 
and perhaps a few other essentials, he regards technology predominantly as a tool for distraction.

Zapffe's other comment on future biotechnology is found in On the Tragic:

Aldous Huxley (Brave New World) has thought about an extinction of the metaphysical need through control of the genes. Speculations about different possibilities in this direction have so far, however, such a thin foundation that for our views on the tragic it is nothing but a curiosity. ${ }^{42}$

In both of these discussions, it is interesting to take notice of Zapffe's reasons for being dismissive. In the dialogue with Tønnessen, Zapffe suggests that biotechnologies, like other technologies, can only provide superficial solutions to the challenges that humans are facing. He does not consider the possibility that biotechnologies could, in virtue of being biotechnologies, bring about changes to human nature and thus, potentially, to the human condition. In his brief discussion of Brave New World, Zapffe does concede that biotechnology could, at least in theory, alter our metaphysical needs, and thus not merely be a tool for distraction. He is nevertheless dismissive, but now on the grounds that he thinks that we are very far away from developing the relevant technologies.

Insofar as the latter is Zapffe's reason for being dismissive, his view is compatible with the proenhancement position. Since the pro-enhancement position is a normative position- that enhancement would be good and that we have reasons to try to pursue them - that position is compatible with the empirical belief that it is very difficult to enhance human capacities or that this will only be achievable in the remote future. Admittedly, if one holds that successful enhancement is impossible, or nearly impossible, there is a sense in which one could not hold a pro-enhancement position. Even in that case, however, one could concede that enhancements would be good if they were to become feasible, and be ready to embrace enhancement technologies in the event that, contrary to what one had expected, they were to become available. ${ }^{43}$

While Zapffe's worldview is formally compatible with enhancement, it does provide us with reasons to

\footnotetext{
$\overline{42}$ Zapffe, Om det tragiske, p. 221.

${ }^{43}$ Note that Zapffe's philosophy, although it does commit one to pessimism about the present state of the world, does not commit one to any particular view on the potential of various emerging technologies. Within wide philosophical boundaries, the potential of various emerging technologies is an open, empirical question.
}

be skeptical of many forms of enhancement. Insofar as we suffer as a result of our cognitive capacities, like Zapffe suggests, we have at least a pro tanto reason to oppose cognitive enhancement, at least in isolation. Moreover, if human lives tend not to be worth living, this is a reason to reject attempts at extending human life spans and at enhancing fertility.

How should we, however, within a Zapffian framework, assess the pursuit of biomedical welfare enhancement? I think Zapffe's framework provides us with strong reasons to pursue this type of enhancement.

One reason is that, in Zapffe's view, we are, by our nature, extremely deficient in happiness, and the more deficient we are in a given respect, the stronger are our reasons to compensate for this deficiency. The worse things are now, the greater is the prospective benefit of being lifted from the current state of affairs to a decently good state of affairs.

Moreover, while Zapffe's pessimistic outlook on human nature thus gives rise to a reason to seek to improve human nature, notice that the central objections to enhancement lose their force in a Zapffian worldview. First, consider the objection that although we may use medical technologies therapeutically, we may not use them to improve upon healthy states. This objection depends on a distinction between a sick state and a healthy human baseline. In Zapffe's view, however, the human baseline is a sick state, characterized by suffering, anxiety, and dread. Insofar as the human baseline is itself sick, it becomes impossible to draw the principled distinction between health and sickness on which this objection to enhancement depends.

For the same reason, the argument that to pursue enhancement is to refuse to be content with anything short of perfection also loses its force. Those who hold an optimistic view of human life can, insofar as they endorse enhancement, reasonably be said to pursue perfection. On Zapffe's pessimistic view, however, the pursuit of enhancement can be justified without the aim of perfection: it can be justified by appeal to the goal of making life worth living.

Finally, consider the objection that the pursuit of enhancement might increase the risk of human extinction. Insofar as this is the case, and extinction is very bad, this can indeed be a good argument for caution. ${ }^{44}$

\footnotetext{
$\overline{44}$ Julian Savulescu and Ingmar Persson defend the opposite view, that we need enhancement - specifically moral enhancement-In order to avoid extinction. See Julian Savulescu and Ingmar Persson, Unfit for the Future: The Need for Moral Enhancement (Oxford: Oxford University Press, [23]).
} 
On Zapffe's view, however, human life (without enhancement) is so bad that extinction is preferable to prolonged human existence. The appeal to increased extinction risk, therefore, also loses its force given Zapffe's pessimistic outlook on life. Indeed, it seems that if we accept Zapffe's premises, we would be justified in pursuing biomedical enhancement even if it involved significant extinction risks. The reason is that we would have everything to win, and nothing to lose, from embarking on this pursuit, since extinction and successful enhancement would both be better than a continuation of our current existence. Within the framework of a Zapffian worldview, therefore, the reasons to pursue enhancements, especially welfare enhancements, are much stronger than the reasons against it. ${ }^{45}$

\section{Enhancement Versus Anti-Natalism}

In response to the pro-enhancement argument presented above, it might be objected that the right course of action, given Zapffe's outlook, is not to seek to improve human life, but rather, to end human life by stopping procreation. It is questionable, however, if this conclusion can be maintained given the prospects of developing welfare enhancement technologies. Admittedly, from an antinatalist perspective, one might have reasons to seek to avoid enhancement technologies that involve the creation of new lives (such as designer babies) and to focus instead on strategies for enhancing people that already exist, or that will at any rate be brought into existence. Even in the case of creating new lives, however, it seems that Zapffe would have to concede that if the right enhancement technologies were to become available, the anti-natalist conclusion would no longer be justified. The reason is that Zapffe's anti-natalist conclusion is justified by direct appeal to the premise that suffering is so abundant, and the good things in life so scarce, that we cannot expect a prospective human life to be worth living. If the

\footnotetext{
$\overline{45}$ One would argue that extensive human enhancement is indeed a form of human extinction, insofar as posthumans would replace humans. This is extinction, not in the sense of humans not creating any ancestors, but in the sense of humans not creating any ancestors that count as human. A complete defense of human enhancement would need to engage with objections of this nature, such as those presented in Nicholas Agar, Humanity's End: Why We Should Reject Radical Enhancement (Cambridge: MIT Press, [24]). I will not, however, engage with that objection here, one reason for which is that, in a suffering-centered framework such as Zapffe's, what matters is whether future beings (if any) suffer, not whether they count as human. Thanks to an anonymous reviewer for raising this issue.
}

suffering become significantly less abundant, and the good things became sufficiently prevalent, however, there are no resources left in Zapffe's philosophy that can justify the conclusion that procreation is immoral. Here Zapffe's philosophy departs from Benatar's philosophy, according to which it is (due to the asymmetry thesis) morally wrong to create a new life unless one can be confident that this life will not contain anything bad at all.

Could biomedical welfare enhancements make life genuinely good? A critic might argue that even if we grant that increased control over our brain chemistry could result in reduced feelings of "world-angst and life-dread," to develop and deploy this type of technology would merely be to engage in a means of suppression for the same reason that isolation, anchoring, and distraction are means of suppression: It would just be a way to avoid confrontation with the grim realities of life. In assessing this objection, however, keep in mind that to the extent that it is the suffering itself that is the problem, an intervention that effectively reduced suffering would, to the extent that it did, not merely make the problem appear to go away: it would genuinely reduce the problem.

Here it might be said, in response, that even if we humans become much happier in the future than we are now, there would still be vast amounts of suffering elsewhere in nature. Richard Dawkins describes this problem vividly in River out of Eden:

The total amount of suffering per year in the natural world is beyond all decent contemplation. During the minute that it takes me to compose this sentence, thousands of animals are being eaten alive, others are running for their lives, whimpering with fear, others are being slowly devoured from within by rasping parasites, thousands of all kinds are dying of starvation, thirst and disease. ${ }^{46}$

How could we, as intelligent and compassionate beings, be happy in such a world without willfully closing our eyes to what is going on around us? Would we not need to engage in suppression in order to remain happy? While that might perhaps be the case, there are defenders of welfare enhancement who suggest that, in a long-term perspective, we should seek not just to eliminate human suffering, but suffering throughout the

\footnotetext{
$\overline{46}$ Richard Dawkins, River Out of Eden (New York, NY: Basic Books: 131-32
} 
natural world. The most influential theorist in this tradition, David Pearce, writes that it should be a long-term aim for humanity to "redesign the global ecosystem, and rewrite the vertebrate genome to get rid of suffering in the rest of the natural world too. For non-human animals don't need liberating; they need looking after." While Pearce concedes that this is not doable with today's technologies, he suggests that - seen in light of the enormous progress that has taken place in medical science over just the last century - the exponential growth of computer power and nanorobotic technologies has the potential, over the decades and centuries ahead, to vastly expand of powers. That power, Pearce suggests, should be pursued with the aim of reducing the suffering (and if possible: promoting the bliss) of all sentient beings. $^{47}$

Insofar as a Zapffian is distraught, not just by human suffering, but also by the suffering that continually takes place in wild nature, they should endorse Pearce's suggestion. Just as in the case of human welfare enhancement, it seems that there would be everything to win, and nothing to lose, from aiming at the long-term welfare enhancement of animals. Notice, moreover, that insofar as a Zapffian is genuinely concerned about suffering in nature at large, it is unclear how they could be justified in concluding that it is even morally permissible to phase out humanity. ${ }^{48}$ The reason is that although the phasing out of humanity would eliminate all human suffering, it would do nothing to eliminate suffering in wild nature. Quite possibly, if humans went extinct, there would be more, rather than less, wild animals, and therefore, every year, there would continue to be billions of sentient beings that are born into an existence that, for a great many of them, is characterized by hunger, fear, and pain, and in which just a minority survives into adulthood. In this respect, to phase out humanity, rather than being a genuine solution to the problem, would be a means of suppression: It would be to shut out the horrors of the world by means of wiping out the human intellect. Insofar as one is concerned with preventing suffering, however, the right way forward is not to wipe out the intellect that is painfully aware of those horrors, but rather, to put the intellect to use in the fight against suffering.

Ideas such as those just sketched arguably belong to the realm of transhumanism. It might be easy assume,

\footnotetext{
$\overline{47}$ Pearce, David, "The Abolitionist Project." Accessed October 5, 2020. www.abolitionist.com [25]

48 Thanks to an anonymous reviewer for making this point.
}

moreover, that this must make them very alien to a Zapffian outlook on the world. Despite his dismissals of technology, however, Zapffe makes several claims in On the Tragic that are highly congenial to transhumanism. The best world, he maintains, would be one in which "all humans extend their mind and refine their sensitivity, taking a sympathetic stance toward their fellow humans and seeking to find and realize a meaningful existence as a unity, of themselves and of humanity." 49 A just world order, moreover, is a "a world order where all has order, plan, and meaning, where fates are adequate to needs, where everything ends up in a way that is acceptable to everyone's judgement." Finally, Zapffe suggests, there is a deep-seated drive in us to give shape and form "not just houses and landscapes but the whole of the universe after human ideals," and to let our highest ideals "radiate through eternity and infinity with love and spirit."

Presumably, Zapffe wrote these formulations with the aim of showing how far the present world is from meeting the standards for what we could accept as good. While it is true that this underscores his pessimistic outlook, it also invites a question: Why should we not at least try to bring about a state of affairs that would be acceptable? Insofar as Zapffe grants that we have reason to promote what is good (which is a very modest thing to grant), his philosophy appears to lead to the conclusion that we should pursue quite radical forms of biomedical enhancement.

\section{Conclusion}

I have had two aims in this paper. The first has been to provide an outline and interpretation of Zapffe's pessimism-based argument for anti-natalism, and through that, to make his arguments accessible to English speaking philosophers. The second aim has been to argue that if one accepts a bleak outlook on life, such as Zapffe's, one should embrace enhancement and reject anti-natalism. Indeed, it is not the optimists of this world, but rather the pessimists, who should be the most eager supporters of attempts at developing enhancement technologies. While people who believe that things are going pretty well might have reasons to take a

\footnotetext{
$\overline{49}$ Zapffe, Om det tragiske, 361 .

${ }^{50}$ Ibid., 69

${ }^{51}$ Ibid., 151
} 
conservative stance and defend the status quo, those with a gloomier outlook do not- and the darker they take the human predicament to be, the more eager they should be in their embrace of human enhancement.

Funding Open access funding provided by OsloMet - Oslo Metropolitan University.

Open Access This article is licensed under a Creative Commons Attribution 4.0 International License, which permits use, sharing, adaptation, distribution and reproduction in any medium or format, as long as you give appropriate credit to the original author(s) and the source, provide a link to the Creative Commons licence, and indicate if changes were made. The images or other third party material in this article are included in the article's Creative Commons licence, unless indicated otherwise in a credit line to the material. If material is not included in the article's Creative Commons licence and your intended use is not permitted by statutory regulation or exceeds the permitted use, you will need to obtain permission directly from the copyright holder. To view a copy of this licence, visit http://creativecommons.org/licenses/by/4.0/.

\section{References}

1. Roser, M. and Ortiz-Ospina, E. n.d. Number of births and deaths per year, world. OurWorldInData.org. University of Oxford. https://ourworldindata.org/grapher/births-anddeaths-projected-to-2100

2. Benatar, David. 2006. Better never to have been: The harm of coming into existence. Oxford: Oxford University Press.

3. Bible. n.d. English standard version.

4. Zapffe, P.W. "The Last Messiah," translated by Gisle Tangenes, Philosophy Now, Issue 45: March/April 2004. https://philosophynow.org/issues/45/The Last Messiah

5. Uexküll, J von. 2010. A foray into the worlds of animals and humans: With a Theory of Meaning. Translated by Joseph D. O’Neil. Minneapolis: University of Minnesota Press.

6. Zapffe, P.W. 2015. Om det tragiske. Oslo: Pax.

7. Haave, J. 1997. "Innledning" in Peter Wessel Zapffe, Kulturelt nødverge: Zapffes etterlatte skrifter Oslo: Pax forlag.

8. Hessen, D.O. 1999. "Zapffe og den biologiske analyse" in $E t$ liv på mange vis: En antologi om Peter Wessel Zapffe, Inga Bostad and Dag O. Hessen (ed.) Oslo: Pax forlag.
9. Zapffe, P.W. 1999. Den Sidste Messias. in Kulturelt nødverge, Jørge Haave (ed.) Oslo: Pax, 51-62.

10. Kahane, Guy. 2014. Our cosmic insignificance. Nous 48 (4): $745-772$.

11. Tangenes, G. 2004. The view from mount Zapffe. Philosophy Now 45.

12. Zapffe, Peter Wessel, and Herman Tønnessen. 1983. Jeg velger sannheten. Oslo: Universitetsforlaget.

13. Schopenhauer, A. 1969. The world as will and representation. Translated by E. F. J. Payne. New York: Dover Publications.

14. Schopenhauer, A. 1971. Parerga and Paralipomena. Translated by E. F. J. Payne. Oxford: Oxford University Press.

15. Magnusson, Erik. 2019. How to reject Benatar's asymmetry argument. Bioethics 33: 674-683.

16. Giubilini, Alberto, and Sagar Sanyal. 2016. Challenging human enhancement. In The ethics of human enhancement: Understanding the debate, ed. Steve Clarke, Julian Savulescu, Tony Coady, Alberto Giubilini, and Saga Sanyal, 1-24. Oxford: Oxford University Press.

17. Douglas, Thomas. 2008. Moral enhancement. Journal of Applied Philosophy 25 (3): 228-245.

18. Buchanan, Allen E. 2011. Beyond humanity? The ethics of biomedical enhancement. Oxford: Oxford University Press.

19. Bostrom, Nick. 2005. In defense of posthuman dignity. Bioethics 19 (3): 201-214.

20. Kass, Leon R. 2003. Ageless bodies, happy souls: Biotechnology and the pursuit of perfection. The New Atlantis 1: 9-28.

21. Sandel, Michael. 2009. The case against perfection. Cambridge: Harvard University Press.

22. Zapffe, P.W. 1997. Opplevelsestilbud og opplevelsesbehov in Peter Wessel Zapffe, Kulturelt nødverge: Zapffes etterlatte skrifter. Oslo: Pax forlag.

23. Savulescu, Julian, and Ingmar Persson. 2011. Unfit for the future: The need for moral enhancement. Oxford: Oxford University Press.

24. Agar, Nicholas. 2010. Humanity's end: Why we should reject radical enhancement. Cambridge: MIT Press.

25. Pearce, D. n.d. The Abolitionist Project. Accessed October 5, 2020. www.abolitionist.com

Publisher's Note Springer Nature remains neutral with regard to jurisdictional claims in published maps and institutional affiliations. 